\title{
Conceptualizing Development and Underdevelopment: From Classical Modernization to Contemporary Post-Development Discourse
}

\author{
M. Saiful Islam (corresponding author) \\ Associate Professor \\ Department of Development Studies \\ University of Dhaka, Bangladesh \\ E-mail: saiful.islam@du.ac.bd
}

\author{
Received: August 2, 2018 Accepted: October 10, 2018 Published: October 15, 2018 \\ doi:10.5296/jad.v4i2.13463 URL: https://doi.org/10.5296/jad.v4i2.13463
}

\begin{abstract}
Development, as an ideology and practice, has been a matter of much contestation since its inception at the enlightened period. The way development has been understood, explained and practiced has undergone various experiments and directions over the time. Yet, what development is theoretically and what it should be in practice remains as contested and vague. This article is an attempt to examine the trajectory of development from its origin in the classical modernization to the more contemporary neo-liberal and post-development discourses. It is argued that the way development has been propagated by the modernists as economic growth and positive change has been vehemently challenged by the post-modernists on the ground that development is not only hegemonic, authoritative and dependency creating mechanism that routinely fails and but also produces unintended consequences on the lives of the people. Thus, there has been a growing realization that development needs to be rethought in a way that would promote an alternative development or even an alternative to development. Such a shift in perspectives and continuing deliberations on development has given rise to the question whether development has reached an impasse which needs to be pushed forward. By reviewing the existing literature, this article aims at unfolding the dynamic trajectory of development both as theory and practice, and argues that development is and continues to be an interesting and stimulating topic in social sciences given its vibrant engagement with and implications on various stakeholders both at the global and local contexts.
\end{abstract}

Keywords: Development and underdevelopment, modernization, dependency, world system, post-development, alternative development 


\section{Introduction}

There has been no other concept than development which has been so much a matter of contestation both conceptually and practically. Despite decades of rigorous academic studies and practical involvements, development continues to be illusive and disputed. To many scholars, development is positive progress, whereas significant others consider development as patriarchal, hegemonic, devastating and failure which needs to be abandoned altogether (Nustad, 2001; Jones, 2004; Everett, 1997; Escobar, 1995). On the other hand, development is very much part of our everyday life as well as a matter of politics intricately connected with the state and bureaucratic institutions. Thus, reiterating the concept of development allows us to revisit the ways it has been understood, practiced and challenged. This article is an examination of the trajectory of development to provide readers an overall understanding of development with its contestations and disguises. The history of 'development' dates back to the history of human civilization itself. The idea of the state and development emerged during the settled agricultural period when specialized labour and the state apparatus were deemed required for protecting agricultural lands from the outsiders. The emergence of the state bodies was also required for controlling the increasingly complex social, economic and political relations that were instigated by the settled agriculture and surplus production. The subsequent advent of industrialization, capitalism and modernization in Europe greatly accelerated the process of socio-economic and political advancements as well as the rise of slums, pollution, diseases and inequality (Polanyi, 1944). It was during this particular historical juncture that social theorists like Hegel and Marx thought about development theory to explain economic growth, inequality and the evolution of human life as a whole. Since then the idea of development not only grew in ever complexity but also diffused globally to penetrate every aspect of our life. The objective of this article, however, is not just to give a whole history of the trajectory of development theories, but to illustrate a bird's eye view of different theories that will allow conceptualization of development and its contestations. Methodologically, the article is based on reviewing secondary literature available on development theories and practices. Different journal articles and relevant books on development have been accessed to collect secondary data for this article. To have a holistic understanding of development and underdevelopment, relevant theories have been collated into three broader groups: (1) Classical Marxist theories; (2) Modernization theories; (3) Neo-Marxist theories (Dependency and World system); and Post-development/alternative development discourse.

\section{Classical Marxist Theories}

Karl Marx is one of the earliest influential theorists to explain capitalism and its relationship to development. To adequately understand development and underdevelopment in a capitalist world system, mode of production and the nature of class struggle must be taken into account (Arndt, 1987). The fundamental thesis in a classical Marxist economy is that material economic base determines the superstructure of all social, political, legal and economic institutions, and each society is characterized by struggles between the proletariats, the working class, and the bourgeoisie, the owner of the means of production (Williams, 1991; Cohen, 1978; Calhoun, 1982). Class struggle is considered to be a by-product of capitalism. 
As the inequality and exploitative work relations reach to an intolerable level, the proletariats will instigate a revolution to overthrow the capitalist regime to achieve a more socialist state which would be free from all social injustices, discriminations and exploitations (Leys, 2005).

In classical Marxist perspective, social evolution is described from a linear point of view: from feudalism though capitalism to socialism. The route through which such social change is possible is revolution against the bourgeoisies by the proletariats. It is argued that the pre-existing socio-economic structures are encroached upon by capitalism through surplus production that consequently helps to perpetuate capitalism (Booth, 1985). One important characteristic of modern capitalism is alienation - the separation between producers and their means of production (Barnett, 1988: 67). From a classical Marxist point of view any theory of development that does not take into account the mode of production and class struggle cannot adequately explain the contemporary development discourse (Hunt, 1979; Thompson, 1978; Harvey, 1976). Capitalism has become so pervasive that it spreads even in remote corners of the society and brings all aspects of social relations under it. Such omnipresent characteristics of capitalist mode of production instantly divides the society into the owners of the means of production and those who do not have it but only have two hands to sell their labour. It has become inevitable for the proletariats to sell their labour to the bourgeoisies for a minimum wage to survive. Bourgeoisies, on the other hand, try to maximize profit by super exploiting the workers through minimum wages, poor work environment and long working hours. The Marxist political economy demonstrates that the relationship that emerged between the bourgeoisie and elite classes have since then collaborated in a global and transnational contexts where the resources of the Third World countries are exploited to develop Europe and the West (Escobar, 1995; Wolf, 1982). In the name of development, underdevelopment perpetuates all over the Third World (Frank, 1966, 1967, 1971). Thus, Marxists argue that the development of the West is in fact a result of unequal treatment and exploitation of resources from the Third World.

\section{Modernization Theories and the Illusion of "Trickle Down"}

Modern development economics is believed to have born in Latin America in the 1930s as a response to the global depression. The contributors of these early development economics belonged to the structuralist or modern school of thought who sought to frame a comprehensive theory of development (Modernization theory) with explicit anti-communist political agenda (Bernstein, 1971; Roxborough, 1988; Chirot \& Hall, 1982). In the postwar period during the 1950 s social scientists in the West got particular interest in understanding and explaining development from an optimistic point of view. They realized that the newly independent nation-states possess a great potential for economic and political success as long as they are guided by the already developed countries of the West through industrialization, trade and investment. Although the word 'modernization' became popular in the $1960 \mathrm{~s}$, its specific meaning remained vague and diverse. Modernization is generally referred to as the appearance of a socioeconomic system which emerged in Europe and subsequently greatly influenced the world (Giddens, 1991). Although it is very difficult to credit a single modernization theory, main ideas and postulations can be gleaned from Walt Whitman 
Rostow's (1960) Stages of Economic Growth: A Non-Communist Manifesto, which is considered to be the pioneer in modernization theory. His main argument lies in different stages of development. Following European economic success, he envisaged that modernization can be achieved through five different stages as follows: Traditional society, Pre-take-off, Take-off, Drive to maturity and High mass consumption.

By Traditional society Rostow refers to those societies that are characterized by limited production facilities, mostly agrarian but lack science, technology and innovative systems and a pre-Newtonian attitude towards natural and physical world. By the pre-take-off stage Rostow refers to those preconditions and processes that "transform a traditional society in the ways necessary for it to exploit the fruits of modern science, to fend of diminishing returns, and thus to enjoy the blessings and choices opened up by the march of compound interest" (Rostow, 1960: 6). At this state the idea of economic progress emerges and economic growth is believed to be the most necessary prerequisite for national progress and overall welfare of the society. A high investment in banks, communication and industrial infrastructure strengthens the overall economic condition of the country. There is a rise in technical education that promotes technical human resources. In the political arena, there has been a drive towards centralized and strong national state.

Take-off is the third stage in which "the old blocks and resistances to steady growth are finally overcome. The forces making for economic progress expand and come to dominate the society. Growth becomes its normal condition" (Rostow, 1960: 7). In all, the traditional ideas, practices and activities are replaced by modern scientific and technological innovations. Economic growth becomes a normal phenomenon at this stage. Commercial and industrial classes gain political power in the course of this transformation. Innovative technologies and large scale financial investments in productive facilities become routine. Britain experienced this stage in between 1780-1800, France and the USA in 1830-60, Russia 1890-1915, whereas India and China in the 1950s-60s. The Drive to Maturity is expected in about 40 to 60 years after take-off period, provided that sustained economic progress is maintained. The economy becomes diversified and at least $10 \%$ of profits are reinvested into the productive facilities that help subsequent continuation of economic progress and maturity.

The age of high mass-consumption is the fifth stage when a shift occurs from industrialization towards a more service sector provision characterized by consumer goods and services. At this stage, per-head income rises to a point when individuals gain a control over their consumption by transcending basic food, shelter and clothing. Number of middle class urban population increases who are mostly skilled and work in the offices or factories. Aside from these economic progressions, a greater amount of material surplus is allocated to the welfare activities in the society. The assembly line of Henry Ford in 1913-14 is considered to be a turning point for the USA to enter into this stage. Western Europe and Japan fully entered into this stage in the 1950s.

According to modernization theory, development and Westernization are considered synonymous. Development is believed to follow a unilineal path through which all societies must pass to become developed i.e. from traditional to modern. The Western developed 


\section{MInstitute Macrothink $_{\text {Int }}$}

countries and the ways they achieved economic progress are prescribed as footprints for the underdeveloped countries to be followed. Modernization theory has been vehemently criticized and almost abandoned by many social scientists (Giddens, 1991; Amin, 1973; 1976; Scott, 1995). One of the major limitations of modernization theory is that it blames less developed countries to be poor because of their internal processes and constraints that hinder development. Modernization school further fails to take into account the role of history and the expansion of global capitalism in producing uneven development. As argued by the neo-Marxist school, the contemporary underdevelopment in the Third World is because of uneven mercantile trade and imperialism where the so-called 'Third Word' is the suppliers of raw materials and the 'First Word' is the producers and consumers of goods (Foster-Carter, 1973; Barrow, 1993; Skocpol, 1980). Rather than taking exploitative global capitalist relationship into account, modernization theory blames internal constraints of the Third World countries as the main obstacles of underdevelopment. Modernization theory is believed to be a 'one-size fits all' formula which insists universal application of Western development (Matunhu, 2011; Tipps, 1973; Billet, 1993). Thus, modernization project, which was once believed to be the prescription for economic growth in the Third World, had in fact resulted into a mechanism of creating high inequality by increasing the gap between the rich and poor.

\section{Neo-Marxist Theories of Development}

The post-World War II and the emergence of the Cold War witnessed an era of economic expansion and polarization of the World order. Given the paradigmatic shift in global political-economy, many social scientists focused on how to study the Third World nation-states, particularly the changing global political economic relationship and the nature of development and underdevelopment of the World (So, 1990:17). Although both Marxist and neo-Marxist theorists consider production relations as the base of socio-political relations, there are considerable points of departure between these two schools of thought. In classical Marxism imperialism has been mostly studied from the perspective of the central capitalist (core) countries, whereas neo-Marxists focus more on the consequences of imperialism and capitalism on the peripheral economies (Parkin, 1979; Albert \& Robin, 1981; Benton, 1984). Classical Marxists believe in historically progressive unilinearity in social change: from feudalism through capitalism to socialism; whereas, neo-Marxists argue that capitalism often leads to underdevelopment and poverty in the peripheries than promoting any development (Mandel, 1968; Poulantzas, 1975; Wallerstein, 1979). Thus, a fundamental stand for the neo-Marxists is that they stress more on psychological and humane liberation instead of radical political revolution for social change. Neo-Marxist school of thought offers two particular theoretical explanations of development and underdevelopment: Dependency theory and the World System theory.

\subsection{Dependency Theory}

Dependency theory has been considered as the first major challenge against Euro-centric development discourse. Dependency theory originated in Latin America in the 1960s in reaction to a number of historical realities. One of them is the failure of Economic 


\section{MInstitute ${ }^{\text {Macrothink }}$}

Commission for Latin America (ECLA), which was predominantly due to adopting inefficient industrial policies in Latin American countries, high tariff imposition on imports, and state subsidies to domestic products which failed to promote development in Latin America (Prebisch, 1950). Other factors that contributed to stimulate dependency theory were the predicament of conformist Marxism and the decline of modernization theory to adequately explain economic stagnation, political despotism and increasing gap between the poor and rich countries (So, 1990; Thomas \& Bernstein, 1983; Amin, 1976; Black, 1966). The dependency school of thought which first emerged in Latin America soon spread in North America primarily through the works of André Gunder Frank, who played an instrumental role in disseminating the ideas of dependency theory by successively publishing his ideas in the influential American journal named Monthly Review. In his works Frank argues that the underdevelopment of the Third World cannot be fully explained and understood within the framework of feudalism or traditionalism; rather, it requires to take into account the historical experiences of colonialism, unequal trade and political-economic relationship between the First World and the Third World countries (Frank, 1966, 1967, 1971). Frank demonstrated that India and China were advanced civilizations along with economic potentials before encountering colonialism in the eighteenth century.

It was colonialism, foreign domination and the extract of resources from the colonized countries that restricted their economic development. India would have experienced development long before if they did not have to face colonialism. Despite development potentials, it was that particular historical experience of colonialism that drastically altered the path of development for many Third World countries which modernization theories rarely acknowledge. By recognizing such devastating force of colonialism, Frank (1966) formulates the idea of "development of underdevelopment" to refer to the fact that "underdevelopment is not a natural condition but an artifact created by the long history of colonial domination in the Third World countries" (So, 1990: 97).

André Gunder Frank was particularly critical about the modernization school. He argues that most development theories have originated from the European and North American historical experiences, which grossly failed to explain poverty and underdevelopment facing the Third World countries (Frank, 1967). These countries would never be able to follow the development path of the West, as the former experienced colonial historical reality which the later had never experienced. Thus, Frank argues that we need a different theoretical explanation which does not only blame internal constraints as the causes of underdevelopment; rather, to incorporate external factors that make Third World countries poor and impoverished. In reaction to the modernization theory, Frank proposes a model of "metropolis-satellite" to demonstrate the mechanism of underdevelopment in the Third World countries (Frank, 1969: 6). The idea of "metropolis-satellite" dates back to the colonial period when colonies were established as satellite cities to facilitate exporting resources from the Third World to the metropolis of the First World. Such an idea of "metropolis-satellite" is even relevant to the contemporary economies whereby local cities and villages have become satellites and the provincial cities appear to be the metropolis. A whole chain of dependency is established between the Third World and the First World countries, between the rural 
villages and provincial cities for extracting raw materials, gaining economic profits, minerals and commodities (Tucker, 1999; Schuurman, 1993). By "Development of Underdevelopment" Frank refers to these historical and colonial processes through which First World countries became developed by exploiting recourses from the Third World countries, thereby making the Third World underdeveloped and impoverished (Frank, 1966).

\subsection{World-System Theory}

In the 1970s, a number of events in the world-economy signaled the inability of the modernization and dependency schools of thought to explain world development. Among these issues were: (1) the economic miracle of East Asian countries such as Taiwan, Hong Kong, Japan, South Korea, Singapore, and Latin American countries such as Brazil, which disproved dependency model; (2) the crisis and economic stagnation of many socialist states and their increasing market opening to the capitalist world economy that signaled the bankruptcy of the radical Marxism; (3) the Sino-Soviet split; (4) the Watergate crisis, the Vietnam war, protectionist economy, inflation and economic stagnation of the USA, which signaled the demise of American hegemony in the world capitalist economy (So, 1990; Stein, 1999; Black, 1999; Tucker, 1999; Luton, 1976). Given such changing global political economic contexts, the time was up to rethink development theory and practice. Being influenced by André Gunder Frank and the broader socio-geographical history of Braudel (1972), Wallerstein and his followers proposed a new development theory which is popularly known as World System Theory (Wallerstein, 1974, 1979).

The main argument of the world-system theory is that development and underdevelopment cannot be adequately explained without taking into account the global world system. Any understanding of development based on the market and economy of the single nation-state would be incomplete and misleading. The central assertion of world-system theory is that the global capitalist economy has been in existence since the 16th century onwards, which subsequently engulfed almost all parts of previously isolated and self-sufficient societies into a complex world system (Schuurman, 1993; Leys, 2005; Kothari \& Minogue, 2002). Such expansion did not only culminate into geographical broadening of the world economy, but also produced socioeconomic deepening among different continents of the interconnected world. As a result of such increasing economic interactions, Wallerstein argues that a tripartite hierarchical structure was observed consisting of the core, periphery and semi-periphery countries. These three zones differ from each other in terms of "degree of political centralization, organization of labour, and main products" (Stein, 1999: 11).

According to world-system theory, the core countries dominate the world economy. These core countries are industrialized, highly developed in political centralization and rich in productive resources and accumulated surplus. Core countries are further characterized by diversified economic activities which were intensified by skilled labour force that produce finished products for local markets and export surplus to the peripheral countries. The peripheries, on the other hand, are those countries that mainly export agricultural products and raw materials to the core and semi-peripheral countries. They produce lower order goods by cheap labour inputs. Politically, these peripheral countries are characterized by 'weak' 
rulers who are often dependent and blessed by the core politics (So, 1990). The political and economic hegemony of the core countries allow them to accumulate resources and surplus from the peripheries mainly through unequal and asymmetric exchange of goods and trade relations (Wallerstein, 1974). The military and technological advancement of the core countries also enable them to set the terms of trade with the peripheral economies. In between the core and the periphery, there exists another zone called semi-periphery countries which are those countries that work as buffer zone between the core and the periphery. These semi-peripheral countries are often considered as a manufacture hub that import advanced technologies from the core and raw materials from the periphery for producing goods to export back to the core economies. The Newly Industrialized Countries (NICs) such as Singapore, Hong Kong, South Korea, Brazil, and such emerging economies as India and China are examples of what Wallerstein calls as semi-periphery countries.

Although world-system theory provides a fresh understanding of global development and underdevelopment, it is again not beyond criticism. One major limitation of this postulation is the fact that it ignores socio-cultural and political diversities in the Third World. It also ignores class analysis within a system. Third World countries are not just the passive subjects to experience domination from the core countries; rather, there are evidences of interregional trade and economic alliances and cooperation that contribute to the growth of regional and domestic production, consumption and investments in the Third World (Sella, 1977; Skocpol, 1977).

\section{Post-development Discourse and Beyond}

Many social scientists in recent times believe that development, as an ideology and practice, has reached a state of deadlock which needs to be moved forward through both theoretical and methodological reclamations (Friedman, 2006; Matthews, 2004.). Those who are talking about alternative or post-development discourse are mostly anthropologists influenced by Foucault who rejects the naïve and essentialist characteristics of development. The main argument of post-development discourse is that "development has done more than just fail, for it has actually created the conditions of poverty that it purports to address" (Friedman, 2006: 202). When earlier development theories consider development as a tool to Westernize or modernize the Third World countries, Post-development, on the other hand, vehemently criticizes such assertion of homogenizing and universalizing the world. Instead, they go on to argue against "cultural imperialism, CocaColonization, McDonaldization and the familiar cultural homogenization thesis, according to which Western media, advertising and consumerism induce cultural uniformity" (Nederveen Pieterse, 2000: 178). They consider development not just as a powerful mechanism through which 'non-Western' or 'Third World' countries are identified and created, but also installs a mechanism of domination, exploitation and management of the Third World (Escobar, 1995; Islam, 2017). They push development beyond its structural discourse to reinforce the existing interconnections between Knowledge, power and poverty (Sachs, 1992). Post-development immediately gained popularity in the 1990s and many of them started to believe that it may help create a space that would allow imagining an alternative to development, or to envisage the so-called development from below (Escobar, 1988, 1991, 1992, 1995, 1997, 2000, 2004; Ferguson, 
1990, 1997; Esteva, 1992; Everett, 1997; Mohan, 1997; Nederveen-Pieterse, 2000; Nustad, 2001; Rahnema \& Bawtree, 1997; Friedman, 2006; Kothari, 1988).

Some theorists in the post-development discourse consider development as "devil", which creates poverty, dependency and high inequality that it actually aims to reduce. Far from improving these conditions, development in fact creates a condition that governmentalizes and controls people on the ground (Nustad, 2001; Mohan, 1997). It is argued that through international financial organizations and development institutions, Western hegemony and authority are perpetuated. Indigenous people in the peripheries have become further marginalized and victims of progress (Bodley, 2008; Islam, 2004, 2010, 2015). James Ferguson (1990) in his leading book The Anti-Politics Machine argues that development appears to be a factor that produces unintended consequences in the lives of the beneficiaries under operation. Drawing upon examples from Lesotho, he argues that development projects often extend political and bureaucratic control over the local population which adversely affect them.

In the post-development discourse, Arturo Escobar has been particularly influential that he criticizes hegemonic development practices and calls for an alternative development model. In his book Encountering Development: The Making and Unmaking of the Third World, Escobar considers development as a "historical construct that provides a space in which poor countries are known, specified and intervened upon" (Escobar, 1995: 45). By disapproving contemporary development practices, Escobar argues that it is largely the North or industrialized World that creates the Third World to win the markets and raw materials from them (Escobar, 1995: 30). Escobar (1995: 44) argues that:

Development was - and continues to be for the most part - a top-down, ethnocentric, and technocratic approach, which treated people and cultures as abstract concepts, statistical figures to be moved up and down in the charts of progress. Development was conceived not as a cultural process (culture was a residual variable, to disappear with the advance of modernization) but instead as a system of more or less universally applicable technical interventions intended to deliver some 'badly needed' goods to a 'target' population. It comes as no surprise that development became a force so destructive to Third World countries, ironically in the name of people's interest.

Escobar further argues that the way development has been practiced through different international, regional and local institutions, financial organizations and experts make sure that the world is put together to ensure certain processes of ruling (Escobar, 1991: 674). Thus, for Escobar, development is authoritative and a mechanism of exercising power to dominate over the so called Third World countries. In order to eliminate such hegemony of Western-biased development institutions and to enhance a humanistic alternative, Escobar calls for an abandonment of the entire project of development, and proposes alternatives to development, which he further clarifies as (Escobar, 1991: 675):

The abandonment of the whole epistemological and political field of postwar development... A rejection of the ethnocentric, patriarchal, and ecocidal character of development models; a defense of pluralistic grassroots movements, in the belief that these movements, and "new social 


\section{MInstitute Macrothink $_{\text {Int }}$}

movements" in general, may be providing a new basis for transforming the structures and discourses of the modern developmentalist states in the Third World; and a conviction that we must work toward a relation between truth and reality different from that which has characterized Western modernity in general and development in particular.

His vision of alternative development is based on the argument that individuals must be appreciated as an active agent of development; rather than just a passive victim of unintended consequences of development. In order to establish such a humane alternative it requires a rethinking of the ways in which development and its beneficiaries have been understood, explained and acted upon (Escobar, 2000; 2004). It demands an overall change in the behavior and attitude towards the people on the ground, whereby development institutions and planners would listen to the actual beneficiaries for whom development projects are planned and executed. As Escobar (1991: 678) rightly points out:

It will be necessary to renew our way of listening to the voices of different groups of people in the Third World, without making them into signs of a need for development, and to renew our awareness of the suffering caused by human institutions and actions, development or otherwise.

To materialize alternative development in practice, a number of key elements have been identified. Firstly, it focuses on how the prevailing sociocultural traditions and practices of the local community could be a potential source of alternative development. Secondly, efficient use of local indigenous knowledge system, human and social capital, and natural resources could be a viable source of self-determination and self-sufficiency. Finally, it requires a bottom-up participatory development process whereby local people participate in all phases of development design and implementation of activities, thereby empowering the local community and sustaining development (Wright, 1988; Islam, 2004; 2005; 2010; 2015)

It has been very clear at this point of discussion that post-development discourse is a radical departure from its earlier hegemonic and structural development theories. It seeks to change the top-down development practices by arguing that such policies and practices are nothing but the replacement of the earlier colonial hegemony through which western countries exploit, dominate and maintain control and supremacy over the Third World. Post-development school demands an alternative way of promoting development that would protect self-determination of the local people, ensure environmental sustainability and make development projects beneficial for the local community. It is argued that the way development has been understood and practiced thus far have conceived local beneficiaries as passive recipients; post-development discourse, on the other hand, envisages local people as active agents of development who enthusiastically take part in all phases of development intervention. Very clearly, earlier development approaches are mostly macro in perspective, whereas post-development and its variants are essentially based on micro initiatives of promoting development that brings development closer to the people. Despite such strengths of post-development, many others criticize that the approach is quite 'ideal type' which may not be feasible to attain in practice. The challenges of post-development remain on how to practice and promote this approach in reality, since we do not have much ethnographic evidences that claim the successful implementation of such development approaches. Others 
argue that post-development is merely a theoretical jargon which fails to offer any sort of alternatives (Kothari \& Minogue, 2002; Leys, 2005).

\section{Conclusion}

Having discussed the trajectory of development from its classical to contemporary contexts, it has been quite evident that development has been variously understood, explained and practiced. The way development has been previously prescribed and practiced as a mechanism of promoting industrialization and economic growth has recently been shifted towards a more humanistic approach to promote development in a compassionate manner by upholding self-help, self-determination and sustainability. Rather than being overly dependent on development organizations and financial institutions, contemporary development discourse envisages resource mobilization on the ground and reconciling indigenous and modern technologies at the community level so that sustainable development with local ownership could be achieved. Shifting away from earlier top-down development practices, contemporary post-development discourse focuses on bottom-up approaches where local priorities, needs and aspirations would be appreciated. Keeping local people at the center of all development activities, recent development initiatives focus on how to engage local people into planning, implementing, monitoring and evaluating development activities. Thus, development has changed both in theories and practices, and in ideologies and conceptualizations. Development institutions continue to grow and penetrate to the local communities with their vested interests, whereas community people also become aware of their rights, privileges and entitlements which enlighten them to see development as a choice. They continue to challenge and even resist development on the ground. Such a vibrant engagement of different stakeholders such as the local communities, development organizations and academics make development even more interesting both in theories and practices, and continue to be so in the years to come.

\section{References}

Albert, M., \& Robin H. (1981). Marxism and Socialist Theory. Boston: South End Press.

Amin, S. (1973). Neo-colonialism in West Africa. Harmondsworth: Penguin.

Amin, S. (1976). Uneven Development. Brighton, Sussex: Harvester Press.

Arndt, H. W. (1987). Economic Development: The History of an Idea. Chicago: University of Chicago Press.

Barnett, T. (1988). Sociology and Development. London: Hutchinson.

Barrow, C. W. (1993). Critical Theories of the State: Marxist, Neo-Marxist and Post-Marxist. Wisconsin: The University of Wisconsin Press.

Benton, T. (1984). The Rise and Fall of Structural Marxism. New York: St. Martin's Press. https://doi.org/10.1007/978-1-349-17548-2

Bernstein, H. (1971). Modernization Theory and the Sociological Study of Development. Journal of Development Studies, 7(2), 141-160. https://doi.org/10.1080/00220387108421356 


\section{MInstitute Macrothink $_{\text {Int }}$}

Journal of Asian Development

ISSN 2377-9594

2018, Vol. 4, No. 2

Billet, B. L. (1993). Modernization Theory and Economic Development: Discontent in the Developing World. Westport: Praeger Publishers.

Black, C. E. (1966). The Dynamics of Modernisation. New York: Harper and Row

Bodley, J. H. (2008). Victims of Progress. London: AltaMira Press.

Booth, D. (1985). Marxism and Development Sociology: Interpreting the Impasse. World Development, 13(7), 761-787. https://doi.org/10.1016/0305-750X(85)90107-X

Braudel, F. (1972). The Mediterranean and the Mediterranean World in the Age of Philip II, 1. New York: Harper and Row.

Calhoun, C. J. (1982). The Question of Class Struggle: Social Foundations of Popular Radicalism during the Industrial Revolution. Chicago: University of Chicago Press.

Chirot, D., \& Hall, T. D. (1982). World-System Theory. Annual Review of Sociology, 8, 81-106. https://doi.org/10.1146/annurev.so.08.080182.000501

Cohen, G. A. (1978). Karl Marx's Theory of History: A Defence. Oxford: Oxford University Press.

Escobar, A. (1988). Power and Visibility: Development and the Invention and Management of the Third World. Cultural Anthropology, 3(4), 428-443. https://doi.org/10.1525/can.1988.3.4.02a00060

Escobar, A. (1991). Anthropology and the Development Encounter: The Making and Marketing of Development Anthropology. American Ethnologist, 18(4), 658-682. https://doi.org/10.1525/ae.1991.18.4.02a00020

Escobar, A. (1992). Imagining a Post-Development Era? Critical Thought, Development and Social Movements. Social Text, 31(32), 20-56. https://doi.org/10.2307/466217

Escobar, A. (1995). Encountering Development: The Making and Unmaking of the Third World. Princeton: Princeton University Press.

Escobar, A. (1997). "The Making and Unmaking of the Third World through Development." In Majid Rahnema and Victoria Bawtree (eds.), The Post-Development Reader, 85-93. London: Zed Books.

Escobar, A. (2000). Beyond the Search for a Paradigm? Post-development and Beyond. Development, 43(4), 11-14. https://doi.org/10.1057/palgrave.development.1110188

Escobar, A. (2004). Beyond the Third World: Imperial Globality, Global Coloniality and Anti-Globalisation Social Movements. Third World Quarterly, 25(1), 207-230. https://doi.org/10.1080/0143659042000185417

Esteva, G. (1992). "Development." In Wolfgang Sachs (ed.), The Development Dictionary: A Guide to Knowledge as Power, 6-26. London: Zed Books.

Everett, M. (1997). The Ghost in the Machine: Agency in "Poststructural" Critiques of 
Development. Anthropological Quarterly, 70(3), 137-151. https://doi.org/10.2307/3317673

Ferguson, J. (1990). The Anti-politics Machine: "Development", Depoliticization, and Bureaucratic Power in Lesotho. Minneapolis: University of Minnesota Press.

Ferguson, J. (1997). "Anthropology and Its Evil Twin: 'Development' in the Constitution of a Discipline". In Frederick Cooper and Randall Packard (eds.), International Development and the Social Sciences, 150-175. Berkeley: University of California Press.

Foster-Carter, A. (1973). Neo-Marxist Approaches to Development and Underdevelopment. Journal of Contemporary Asia, 3(1), 7-33. https://doi.org/10.1080/00472337308566845

Frank-André, G. (1966). The Development of Underdevelopment. Monthly Review, 18. 17-31. https://doi.org/10.14452/MR-018-04-1966-08_3

Frank-André, G. (1967). Capitalism and Underdevelopment in Latin America: Historical Studies of Chile and Brazil. New York: Monthly Review Press.

Frank-André, G. (1969). Latin America: Underdevelopment or Revolution. New York: Monthly Review Press.

Frank-André, G. (1971).Capitalism and Underdevelopment in Latin America. London: Penguin Books.

Friedman, J. T. (2006). Beyond the Post-Structural Impasse in the Anthropology of Development. Dialectical Anthropology, 201-225. https://doi.org/10.1007/s10624-007-9006-9

Giddens, A. (1991). The Consequences of Modernity. Stanford: Stanford University Press.

Harvey, D. (1976). Labor, Capital, and Class Struggle around the Built Environment in Advanced Capitalist Societies. Politics \& Society, 6(3), 265-295. https://doi.org/10.1177/003232927600600301

Hunt, E. K. (1979). The Categories of Productive and Unproductive Labour in Marxist Economic Theory. Science and Society, 43(3), 303-315.

Islam, S. (2003). Acculturation and Identity Crisis: An Anthropological Study on the Gorrat Community of Barind Tract in Bangladesh. South Asian Anthropologist, 3(1), 5-17.

Islam, S. (2004). "Who Benefits, How Benefits": The Political Economy of Grameen Bank's Microcredit Programme in Rural Bangladesh. Oriental Anthropologists, 4(1), 1-17.

Islam, S. (2005).Oscillating between Marginality and Modernity: Transitional Oraon Cultural Milieu of Northwest Bangladesh. South Asian Anthropologist, 5(2), 179-185.

Islam, S. (2010).Indigenous People, NGOs and the Politics of Alternative Development Discourse in Bangladesh. Dhaka University Journal of Development Studies, 1. 79-89.

Islam, S. (2015). Pursuing Alternative Development: Indigenous People, Ethnic Organization and Agency. London: Palgrave MacMillan. 


\section{Macrothink

Islam, S. (2017). Culture, Health and Development in South Asia: Arsenic Poisoning in Bangladesh. London and New York: Routledge.

Jones, P. S. (2004). When 'Development' Devastates: Donor Discourses, Access to HIV/AIDS Treatment in Africa and Rethinking the Landscape of Development. Third World Quarterly, 25(2), 385-404. https://doi.org/10.1080/0143659042000174879

Kothari, R. (1988). Rethinking Development: In Search of Humane Alternatives. Delhi: Ajanta.

Kothari, U., \& Minogue, M. (2002). "Critical Perspectives on Development: An Introduction". In Uma Kothari and Martin Minogue (eds.), Development Theory and Practice: Critical Perspectives, 1-15. Hampshire: Palgrave.

Leys, C. (2005). "The Rise and Fall of Development Theory". In Marc Edelman and Angelique Haugerud (eds.), The Anthropology of Development and Globalization: From Classical Political Economy to Contemporary Neoliberalism, 109-125. Malden, MA: Blackwell Publishing.

Luton, H. (1976). The Satellite/Metropolis Model: A Critique. Theory and Society, 3(4), 573-581. https://doi.org/10.1007/BF00161298

Mandel, E. (1968). Marxist Economic Theory. New York: Monthly Review Press.

Matthews, S. (2004). Post-development Theory and the Question of Alternatives: A View from Africa. Third World Quarterly, 25(2), 373-384. https://doi.org/10.1080/0143659042000174860

Matunhu, J. (2011). A Critique of Modernization and Dependency Theories in Africa: Critical Assessment. African Journal of History and Culture, 3(5), 65-72.

Mohan, G. (1997). Developing Differences: Post-structuralism \& Political Economy in Contemporary Development Studies. Review of African Political Economy, 73, 311-328. https://doi.org/10.1080/03056249708704265

Nederveen-Pieterse, J. (2000). After Post-Development. Third World Quarterly, 21(2), 175-191. https://doi.org/10.1080/01436590050004300

Nustad, K. G. (2001). Development: The Devil We Know? Third World Quarterly, 22(4), 479-489. https://doi.org/10.1080/01436590120071731

Parkin, F. (1979). Marxism and Class Theory: A Bourgeois Critique. New York: Columbia University Press.

Polanyi, K. (1944). The Great Transformation: The Political and Economic Origins of Our Time. Boston: Beacon Press.

Poulantzas, N. (1975). Classes in Contemporary Capitalism. London: New Left Books.

Prebisch, R. (1950). The Economic Development of Latin America and its Principal Problems. New York: United Nations Economic Commission for Latin America. 
Rahnema, M., \& Bawtree, V. (1997).The Post-Development Reader. London: Zed Books.

Rostow, W. W. (1960). Stages of Economic Growth: A Non-Communist Manifesto. Cambridge: Cambridge University Press.

Roxborough, I. (1988). Modernization Theory Revisited: A Review Article. Comparative Studies in Society and History, 30, 753-761. https://doi.org/10.1017/S0010417500015528

Sachs, W. (1992). "Introduction”. In Wolfgang Sachs (ed.), The Development Dictionary: A Guide to Knowledge as Power, 1-25. London: Zed Books.

Schuurman, F. J. (1993). "Introduction: Development Theory in the 1990s". In Frans J. Schuurman (ed.), Beyond the Impasse: New Directions in Development Theory, 1-48. London: Zed Books.

Scott, C. V. (1995). Gender and Development: Rethinking Modernization and Dependency Theory. Boulder: Rienner Publishers.

Sella, D. (1977). The World System and Its Dangers. Peasant Studies, 6, 29-32.

Sen, A. (2000). Development and Freedom. New York: Anchor.

Skocpol, T. (1977). Wallerstein's World Capitalist System: A Theoretical and Historical Critique. American Journal of Sociology, 82(5), 1075-1090. https://doi.org/10.1086/226431

Skocpol, T. (1980). Political Response to Capitalist Crisis: Neo-Marxist Theories of the State and the Case of the New Deal. Politics and Society, 10(2), 155-201. https://doi.org/10.1177/003232928001000202

So, A. Y. (1990). Social Change and Development: Modernization, Dependency and World-system Theories. London: Sage Publications.

Stein, G. J. (1999). Rethinking World-system: Diasporas, Colonies and Interaction in Uruk Mesopotamia. Tucson: University of Arizona Press.

Thomas, A., \& Bernstein, H. (1983). The Third World and Development. New York: Open University Press.

Thompson, E. P. (1978). Eighteenth-century English Society: Class struggle without class? Social History, 3(2), 133-165. https://doi.org/10.1080/03071027808567424

Tipps, D. C. (1973). Modernization Theory and the Comparative Study of Societies: A Critical Perspective. Comparative Studies in Society and History, 15(2), 199-226. https://doi.org/10.1017/S0010417500007039

Tucker, V. (1999). "The Myth of Development: A Critique of a Eurocentric Discourse". In Ronaldo Munck and Denis O'Hearn (eds.), Critical Development Theory: Contributions to a New Paradigm, 1-26. London: Zed Books.

Wallerstein, I. (1974). The Modern World System. New York: Academic Press.

Wallerstein, I. (1979). The Capitalist World Economy. Cambridge: Cambridge University 
Press.

Williams, R. (1991). "Base and Superstructure in Marxist Cultural Theory." In Chandra Mukerji and Michael Schudson (eds.), Rethinking Popular Culture: Contemporary Perspectives in Cultural Studies, 407-423. Berkeley: University of California Press.

Wolf, E. R. (1982). Europe and the People without History. Berkeley: University of California Press.

Wright, R. M. (1988). Anthropological Presuppositions of Indigenous Advocacy. Annual Review of Anthropology, 17, 365-390. Retrieved from https://doi.org/10.1146/annurev.an.17.100188.002053

\section{Copyright Disclaimer}

Copyright for this article is retained by the author(s), with first publication rights granted to the journal.

This is an open-access article distributed under the terms and conditions of the Creative Commons Attribution license (http://creativecommons.org/licenses/by/4.0/). 